the spirit and letter of this will is now known to the world, though it is strange that it should have been left until 1951 for Mr. Prentiss 'True to tell this fascinating story. But even after Smithson's bequest, it was the remote chance of the death of his nephew some six years later, leaving no child, that gave Washington the glorious opportunity of establishing such a chain of cultural centres.

The United States National Museum with its thirty million objects is perhaps the best known museum in the world. On the other hand, it is seldom realized that nine other organizations, including the National Air Museum, National Gallery of Art, National Collection of Fine Arts, Freer Gallery of Art and the National Zoological Park are centred around the Smithsonian Institution. Has one man ever created such a focus of learning and knowledge and by a stroke of the pen benefited so many millions of his fellow men, chiefly in a country which he had never visited or apparently in which he was not particularly interested ?

The largest part of this vast organization is the United States National Museum, with its six Departments-Geology, Zoology, Botany, Anthropology, Engineering and Industries, and History. Mr. True deals in separate chapters with the work of these Departments, and in a popular and entertaining manner shows how the Museum has made each subject appeal to the general public and yet at the same time provide material for investigation by specialists. In other words, the Museum is both an exhibition and research centre.

In lesser detail, the author outlines the work of the Bureau of American Ethnology, where the history of the American Indians is recorded; fascinates his readers by a description of the wild animals in the Washington Zoo; discusses the rich collections of the National Gallery; and finally relates the many services of the Smithsonian which make available scientific and cultural knowledge in the United States to scholars all over the world.

The book will be read with a touch of envy by those in Great Britain, though coupled with gratitude that the chosen country has fulfilled to the uttermost the vision of James Smithson, the lonely English bachelor. To describe it as an attractive and well-illustrated account for the lay reader and full of suggestive ideas for the museum specialist sums up this entertaining book.

F. S. Wallis

\section{JAPANESE MONOGRAPH OF LICHEN CHEMISTRY}

\section{Chemistry of Lichen Substances}

By Prof. Yasuhiko Asahina and Assoc. Prof. Shoji Shibata (University of Tokyo). Pp. viii +300 . (Tokyo: Published in Japanese by the Kawade Shobo Co., 1949.) 480 yen.

W ILHELM ZOPF in a classic treatise ${ }^{1}$ was the first worker to summarize all the work on the lichen metabolic products then known-some 148 compounds had already been isolated, characterized and named by Zopf, Hesse and other workers-and he attempted to systematize them by a chemical classification. Prof. Y. Asahina reviewed the field in 1939 in an article entitled "Flechtenstoffe" 2 in the light of some one hundred publications from his research school at the University of Tokyo. Later, Prof. T: J. Nolan, of the National University of
Ireland, Dublin, surveyed all the lichen compounds the chemical constitutions of which had been estab. lished, using Asahina's classification with some slight modifications ${ }^{3}$.

Recent work on the isolation and chemistry of these interesting compounds has been carried out by Prof. Alexander Robertson, first at the London School of Hygiene and Tropical Medicine and then at the University of Liverpool, and by Prof. T. R. Seshadri, of the Andhra University, India. Interest in lichen products has been stimulated lately by numerous investigations of their anti-bacterial properties with special emphasis on their activity as inhibitors of the tubercle bacillus. (See a review by Prof. F. Bustinza, University of Madrid ${ }^{4}$ )

This new book by Profs. Asahina and S. Shibata, the first to summarize completely the field of the chemistry of the lichen metabolic products, is a valuable addition to our knowledge of the naturally occurring compounds. Although written in Japanese, it should be of considerable use to English-speaking scientific workers by virtue of its very many structural formulæ and complete literature references. I understand that a translation into English is being contemplated.

This publication, of some three hundred pages, has been written in three sections. Part 1 gives a brief historical sketch of lichen investigations ; a classification of lichen substances into their chemical groups; while a third chapter deals with the methods of extraction, isolation and purification of the various metabolic products.

Part 2 describes in their groups the lichen source, history, properties, and the structural and degradative chemistry of some seventy-six pure compounds which have had their chemistry more or less completely. elucidated. The following compounds, not covered in Prof. Nolan's review, are now described: rangiformic acid; the depsides erythrin, hiascic acid and hypothamnolic acid; pannarin (a depsidone); the anthraquinone pigment fallacin; lichexanthone; two dibenzofuran compounds didymic acid and strepsilin; and the nitrogen-containing bitter substance picroroccellin. Diploicin, an unusual chlorinecontaining depsidone, isolated along with several other chlorinated compounds from the lichen Buellia canescens (Diploücia canescens Dicks), is but scarcely mentioned on p. 122 and should have received more fuller treatment in view of the work of Nolan and his collaborators. Diffractaic acid and $\alpha$-collatolic acid, names assigned to two lichen acids by Prof. Asahina, should be discarded since they are known (and stated) to be identical with the compounds already fully described by Zopf (loc. cit.) as dirhizoninic acid and lecanorolic acid, respectively.

Part 3 consists of chapters discussing the relationships between liehen substances and fungal metabolic products, with particular reference to the hydroxymethylanthraquinones; some biogenetic interpretations of the formation of lichen compounds; and finally some work which has been recorded on the antibacterial properties of numerous lichen products and their derivatives. Author, species and subject indexes are given in English as well as Japanese.

\section{J. C. DACRE}

* "Die Flechtenstoffe in chemischer, botanischer, pharmakologischer und technischer beziehung" (Jena: Verlag von Gustav Fischer, 1907).

${ }^{2}$ Fortschr. Chem. organ. Naturstoffe, 2, 27 (1939).

3 See "Iichen Substances"' in "Thorpe's Dictionary of Applied Chemistry", 7,281 (London: Longmans, Green and Co., 1946). Endeavour, 10, 95 (1951). 